\title{
التطور المالي، رأس المال البشري ونمو الناتج في المملكة العربية السعودية
}

\author{
عبدالله بن محمد بن صالح المالكي

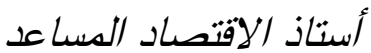

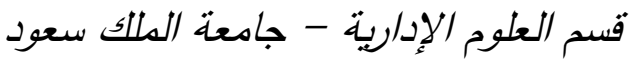 \\ الرياض - المدلكة العربية السعودية
}

المستخص. تبحث هذه الورقة في العلاقة بين التطور المالي، رأس

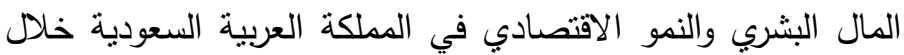

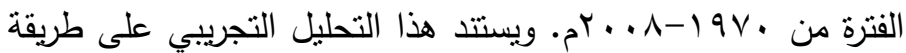

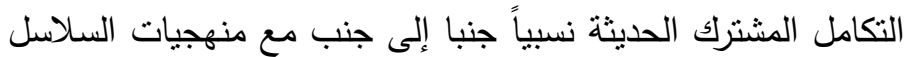

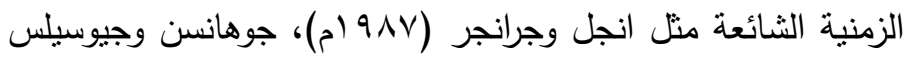

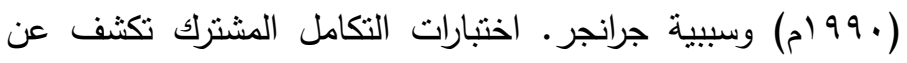
وجود علاقة توازنية طويلة الددى بين التطور المالي ورأس المال

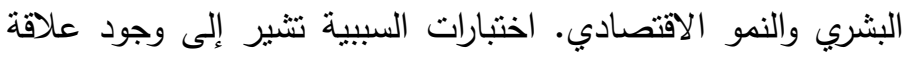

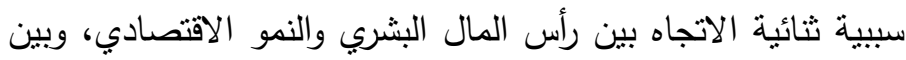

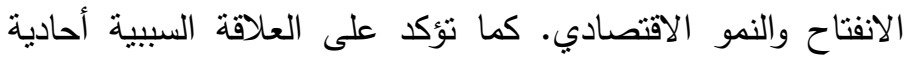

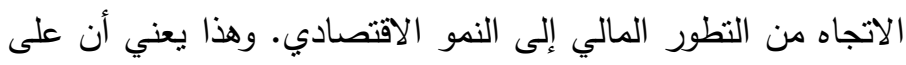

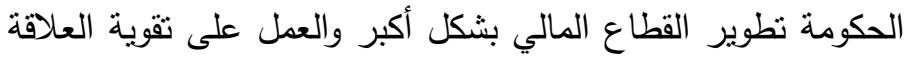
بين القطاع المالي والقطاع الحقيقي في المملكة العربية السعودية. 


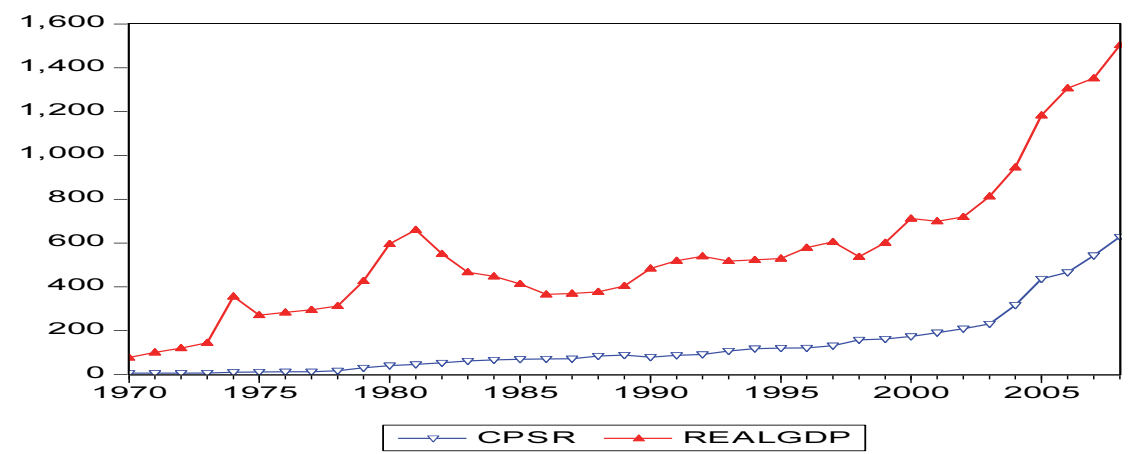

Figure (1). Variable Visual Plots.
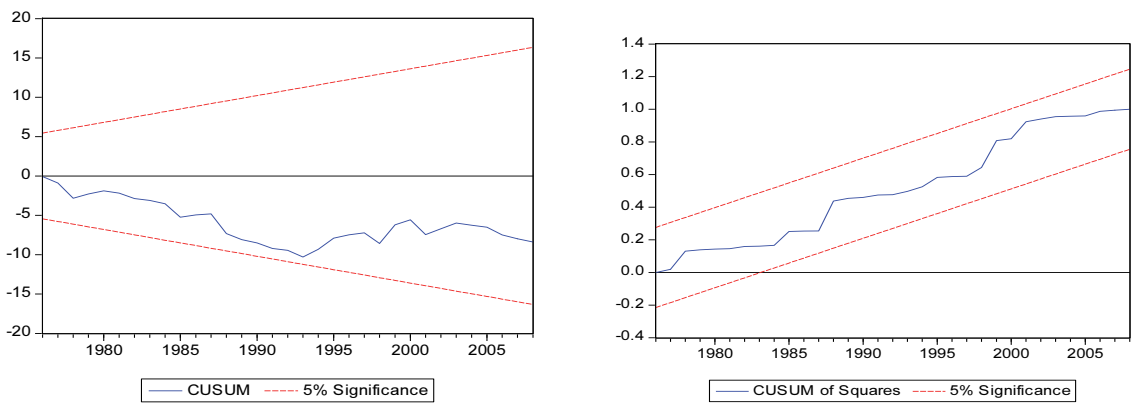

Figure (2). Plots of CUSUM and CUSUMSQ statistics for stability test. 


\section{Appendix}

Table (1A). Description and Source of Data .

\begin{tabular}{|c|c|c|c|}
\hline Variable & Proxy & Description & Source \\
\hline \multicolumn{4}{|l|}{ Dependent variables } \\
\hline $\begin{array}{l}\text { Economic } \\
\text { indicator: } \\
\text { Gross domestic product. }\end{array}$ & LRGDP & $\begin{array}{l}\text { Real gross domestic } \\
\text { product. It is used as a } \\
\text { measure of economic } \\
\text { output. }\end{array}$ & SAMA \\
\hline$\frac{\text { Independent Variables }}{\text { Credit to private sector }}$ & LCPSR & $\begin{array}{l}\text { Total domestic credits } \\
\text { made by commercial } \\
\text { banks and other deposit- } \\
\text { taking bank to the private } \\
\text { sector. It is expected a } \\
\text { positive effect on } \\
\text { dependent variable. }\end{array}$ & IFS \\
\hline $\begin{array}{l}\text { Government expenditure } \\
\text { per capita on education. }\end{array}$ & $\begin{array}{l}\text { LEDUEXPP } \\
\mathrm{C}\end{array}$ & $\begin{array}{l}\text { Total government } \\
\text { spending on education } \\
\text { (general and higher } \\
\text { education) divided by } \\
\text { population. }\end{array}$ & $\begin{array}{l}\text { Ministry of Education \& } \\
\text { UNESCO }\end{array}$ \\
\hline Trade Openness & LOPENNESS & $\begin{array}{l}\text { Actual trade flows such } \\
\text { as imports plus exports as } \\
\text { a percentage of GDP. }\end{array}$ & $\begin{array}{l}\text { SAMA \& Central Dep. Of } \\
\text { Statistics \& information, } \\
\text { Ministry of Economy and } \\
\text { Planning }\end{array}$ \\
\hline
\end{tabular}

All the variables are expressed in national currency (Saudi Riyal) and expressed in logarithm form.
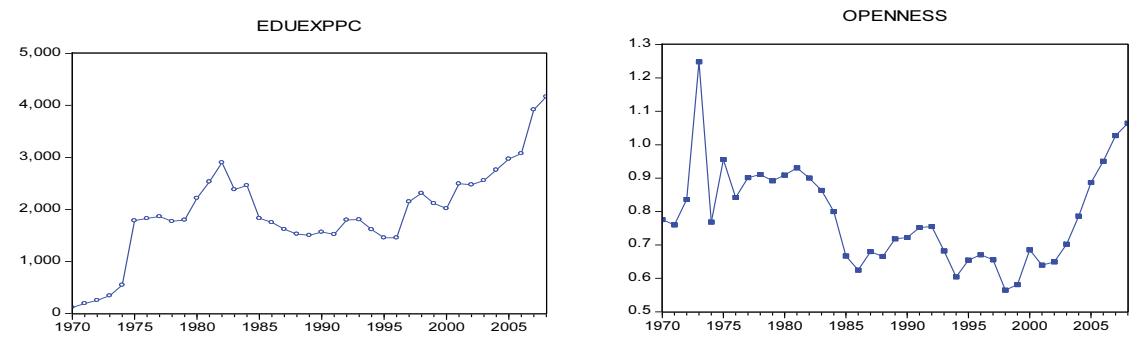
Tang, T.C. and Nair, M. (2002) 'A co-integration analysis of Malaysian import demand function: reassessment from the bounds test', Applied Economics Letters, 9(5): 293-296.

Trabelsi, M. (2002) "Finance and growth: empirical evidence from developing countries, 1960-1990," Centre interuniversitaire de recherche en économie quantitative (CIREQ), Université de Montréal, and IHEC, Carthage, 1-27.

Vaizey, J. (1962) “The economics of education”. London: Faber Limited, 1-165.

Vamvakidis, A. (2002) 'How robust is the growth openness connection? Historical evidence', Journal of Economic Growth, 7(1): 57-80.

Vazakidis, A. and Adamopoulous, A. (2009) "Financial development and economic growth an empirical analysis for Greece". American Journal of Applied Sciences, 6(7): 1410-1417.

Wachtel, P. (2001) Growth and finance: what do we know and how do we know it? International Finance, 4(3): 353-362.

Yay, G. and Oktayer, A. (2009) "Financial development and economic growth a comparative analysis". Romanian Journal of Economic Forecasting,11(3): 56-74.

\section{Web Sites}

http://info.moe.gov.sa/

http://www.uis.unesco.org/ev.php?ID=2867_201\&ID2=DO_TOPIC 
Odhiambo, N.M. (2010) 'Finance-investment-growth nexus in South Africa: an ARDL-bounds testing procedure', Economic and Change Restructuring, 43(3): 205-214.

Onafowora, O. and Owoye, O. (1998) "Can trade liberalization stimulate economic growth in Africa?" World Development, 26(3): 497-506.

Ouattara, B. (2004a) 'Modelling the long run determinants of private investment in Senegal', the School of Economics, Discussion Paper Series 0413, Economics, The University of Manchester, 1-37.

Razin, A. (1977) "Economic growth and education: new evidence", Economic Development and Cultural Change, 25(2): 317-324.

Pesaran, M.H. and Shin, Y. (1995) "Long-run structural modeling", DAE Working Paper Series No 9419. Cambridge Department of Applied Economics, University of Cambridge, 1-40.

Peseran, M.H., Peseran, B. (1997) Microfit 4.0: Interactive Econometric Analysis, Oxford: Oxford University Press, 1-536.

Pesaran, M.H. and Shin, Y. (1999) An autoregressive distributed lag modeling approach to co-integration analysis, in storm, S., ed, Econometrics and Economic Theory in the 20th Century: the Ragnar Frish Centennial Symposium, Cambridge University Press, Cambridge, 1-24.

Pesaran, M.H., Shin, Y. and Smith, R.J. (2001) "Bounds testing approaches to the analysis of level relationships", Journal of Applied Econometrics, 16(3): 289-326.

Pittichis, C.A. (1999) 'Price and income elasticities of disaggregated import demand: results from UECMs and an application,'Applied Economics, 31(9): 1061-1071.

Psacharopoulos, G. (1994) 'Returns to investment in education: a global update', World Development 22(9): 1325-43.

Saci, K. and Holden, K. (2008) "Evidence on growth and financial development using principal components," Applied Financial Economics, 18(19): 1549-1560.

Shaw, E.S. (1973) Financial Deepening in Economic Development. London: Oxford University Press, 1-260.

Schultz, T. (1961) "Education and economic growth, In: Henry, N.B. (Ed.), Social Forces Influencing American Education, 46-88.

Schultz, T. (1981) "Investing in people: the economics of population quality. Berkeley: University of California Press, 1-173.

Schumpeter, J.A. (1911) The theory of economic development. Cambridge: Harvard University Press, 1-255.

Seetanah, B. (2008) Financial development and economic growth: an ARDL approach for the case of the small Island State of Mauritius, Applied Economics Letters, 5(10): 809-813.

Shahbaz M., Ahmed, N. and Ali L. (2008) 'Stock market development and economic growth: ARDL causality in Pakistan', International Researches Journal of Finance and Economics, 14 : 182-195.

Sims, C.A. (1972) 'Money, income and causality', American Economic Review, 62(4): 540-552.

Stock, J. and Watson, M. (1988) 'Testing for common trends', Journal of the American Statistical Association, 83(404): 1097-1107. 
King, R.G. and Levine, R. (1993a) Finance and growth: Schumpeter might be right. Quarterly Journal of Economics, 108(3): 717-737.

King, R.G. and Levine, R. (1993b) 'Finance, entrepreneurship, and growth: theory and evidence', Journal of Monetary Economics, 32(3): 513-542.

Kingdom of Saudi Arabia, Saudi Arabian Monetary Agency (SAMA), Forty-Fifth Annual Report, The Latest Economic Developments, 1430H (2009G), Research and Statistics Department.

Kwiatkowski, D., Phillips, P.C.B., Schmidt, P. and Shin, Y. (1992) 'Testing the null hypothesis of stationarity against the alternative of a unit root: how sure are we that economic time series have a unit root?', Journal of Econometrics, 54(1-3): 159-178. North Holland.

Johansen, S. (1988) 'Statistical analysis of co-integration vectors', Journal of Economic Dynamics Control, 12(2-3): 231-254.

Johansen, S. and Juselius, K. (1990) "Maximum likelihood estimation and inference on co-integration- with applications to the demand for money," Oxford Bulletin of Economics and Statistics 52(2): 169-210.

Jung, W.S. (1986) "Financial development and economic growth: international evidence", Economic Development and Cultural Change, 34(2): 333-346.

Levine, Ross (1997) 'Financial development and economic growth: views and agenda', Journal of Economic Literature, 35(2): 688-726.

Lucas, R.E., Jr. (1988) On the mechanics of economic development, Journal of Monetary Economics, 22(1): 3-42.

MacKinnon J. (1991) Critical values for co-integration tests. In: Engle R, Granger C. (eds) Long-run economic relationships: readings in co-integration. Oxford University Press, Oxford, pp. 267-276.

MacKinnon, J.G. (1996) "Numerical distribution functions for unit root and cointegration tests," Journal of Applied Econometrics, 11(6): 601-618.

Mah, J.S. (2000) 'An empirical examination of the disaggregated import demand of Korea-the case of information technology products', Journal of Asian Economics, 11(2): 237-244.

McKinnon, R.I. (1973) Money and Capital in Economic Development. Washington, DC, USA: Brookings Institution, 1-48.

Ministry of Economy and Planning, Achievements of the Development Plans Facts and Figures, Twenty-Fifth Issue, (1970-2008), Riyadh, Saudi Arabia.

Murinde, V. and Eng, F.S.H (1994) 'Financial development and economic growth in Singapore: demand - following or supply - leading?', Applied Financial Economics, 4(6): 391-404.

Narayan, K.N. and Smith, R. (2005) 'Trade liberalization and economic growth in Fiji: an empirical assessment using ARDL approach', Journal of Asia Pacific Economy, 10(1): 95-115.

Nieh, C. and Wang, Y. (2005) "ARDL approach to the exchange rate overshooting in Taiwan", Review of Quantitative Finance and Accounting, 25(1): 55-71.

Odedokun, M.O. (1996) 'Alternative econometric approaches for analyzing the role of the financial sector in economic growth: time series evidence from LDCs', Journal of Development Economics, 50(1): 119-146. 
Dickey, D.A. and Fuller, W.A. (1981) "Likelihood ratio statistics for autoregressive time series with a unit root," Econometrica, 49(4): 1057-1072.

Edwards, S. (1992) 'Trade orientation, distortions and growth in developing countries', Journal of Development Economics, 39(1): 31-57.

Engle, R.F. and Granger, G.W.J. (1987) "Co-integration and error correction: representation, estimation and testing", Econometrica, 55(2): 251-276.

Engle, Robert F. and Yoo, B.S. (1987) 'Forecasting and testing in co-integrated systems', Journal of Econometrics, 35(1): 143-159.

Elliot, G., Rothenberg, T. and Stock, J. (1996) 'Efficient tests for an autoregressive unit root', Econometrica, 64(4): 813-836.

Fry, M.J. (1978) Money and capital or financial deepening in economic development?. Journal of Money, Credit, and Banking, 10(4): 464-475.

Fuller, W.A. (1976) Introduction to Statistical Time Series. New York, Wiley, 1-728.

Granger, C.W.J. (1969) 'Investigating causal relations by econometric models and cross spectral methods'. Econometrica, 37(3): 428-438.

Granger, C.W.J. (1986) 'Developments in the study of co-integrated economic variables', Oxford Bulletin of Economics and Statistics, 48(3): 213-228.

Granger, C.W.J. (1988) 'Some recent developments in a concept of causality', Journal of Econometrics, 39(1-2): 199-211.

Gujarati, D.N. (2003) Basic econometrics, Mc Graw Hill, fourth edition, United States Military Academy, West Point, 1-1002.

Gupta, K.L. (1984) Finance and economic growth in developing countries. Croom Helm, London, 1-241.

Gurley, J.G. and Shaw, E.S. (1955) Financial aspects of economic development, American Economic Review, 45(9): 515-538.

Gurley, J.G. and Shaw, E.S. (1960) Money in a Theory of Finance (Washington: Brookings Institution), 1-371.

Harbison, F. (1973) "Human Resources as the Wealth of Nations". London: Oxford University Press, 1-173.

Harrison, A. (1996) "Openness and growth: a time-series, cross-country analysis for developing countries", Journal of Development Economics, 48(2): 419-447.

Hassan Kamrul, A.F.M. and Islam Rafiqul, M. (2005) Temporal causality and dynamics of financial development, trade openness and economic growth in vector auto regression (VAR) for Bangladesh, 1974-2003: Implication for Poverty Reduction, The Journal of Nepalese Business Studies, 2(1): 1-12.

Hendry, D.F. (1995) Dynamic Econometrics. Oxford University Press, New York, 1-904.

Hsu, C.M. and Lin, S.M. (2000) 'Financial development and endogenous growth model', Industry of Free China, 9(1): 21-47.

International Monetary Fund (IMF) International Financial Statistics (various years), Washington DC, USA.

Kar. M., Nazlioglu and Agir, H. (2011) Financial development and economic growth nexus in the MENA countries: Bootstrap Panel Granger Causality Analysis. Economic Modeling, 28(1-2): 685-693.

Kennedy, P. (2003) A guide to econometrics, 5th edition, Blackwell Publishers, 1-634.

Khan, S.M. and Senhadji, A.S. (2000) "Financial development and economic growth: an overview”. IMF Working Paper 00/209, 1-23, Washington, D.C, USA. 


\section{References}

Afzal, M., Farooq, M.S., Ahmad, H.K., Begum, I.B. and Quddus, M.A. (2010) 'Relationship between school education and economic growth in Pakistan; ARDL bounds testing approach to co-integration', Pakistan Economic and Social Review, 48(1): 39-60.

Ahmed, J. (2001) "Causality between exports and economic growth: what do the econometric studies tell us?", Pacific Economic Review, 6(1): 147-167.

Akimova, A., Wijeweerab, A. and Dollery, B. (2009) "Financial development and economic growth: evidence from transition economies", Applied Financial Economics, 19(10-12): 999-1008.

Alam, M.I. and Quasi, R.M. (2003) 'Determinant of capital flight: an econometric case study of Bangladesih', International Review of Applied economics, 17(1): 85-103.

Ang, J.B. (2008) 'A survey of recent developments in the literature of finance and growth', Journal of Economic Surveys, Blackwell Publishing, 22(3): 536-576.

Ang, J.S. (2009) Financial Development and Economic Growth in Malaysia. Abingdon. Oxon; New York, NY, Routledge, 1-191.

Anwar, S. and Nguyen, L.P. (2011) 'financial development and economic growth in Vietnam', Journal of Economics and Finance, 35(3): 348-360.

Asteriou, D. and G.M. Agiomirgianakis (2001) "Human capital and economic growth: time series evidence from Greece," Journal of Policy Modeling, 23(5): 481-489.

Bagehot, W. (1873) Lombard Street: A Description of the Money Market. Homewood, Illinois, United States: Irwin, 1-359.

Bardsen, G. (1989) Estimation of long-run coefficients in error correction models. Oxford Bulletin of Economics and Statistics, 51(3): 345-350.

Becker, G. (1962) "Investment in human capital: a theoretical analysis," Journal of Political Economy, 70(5): 9-49.

Brown, R.L., Durbin, J. and Evans, J.M. (1975) Techniques for testing the constancy of regression relations over time. Journal of the Royal Statistical Society, 37(2): 149-163.

Christopoulos, D.K. and Tsionas, E.G (2004) "Financial development and economic growth: evidence from panel unit root and co-integration tests", Journal of Development Economics 73(1): 55-74.

Chyuan, W.W. (2005) The integration of residential real estate market and stock market: assessment from ARDL approach, Master dissertation, University of Utara, Malaysia.

De Gregorio, J. and Guidotti, P.E. (1995) 'Financial development and economic growth', World Development, 23(3): 433-448.

Demetriades, P.O. and Hussein, K.A. (1996) 'Does financial development cause economic growth? Time-series evidence from 16 countries', Journal of Development Economics, 51(2): 387-411.

Demirguc-Kunt, A. and Levine, R. (1996) 'Stock markets, corporate finance and economic growth: an overview', World Bank Economic Review, 10(2): 223-239.

Dickey D.A. and Fuller W.A. (1979) "Distribution of the estimators for autoregressive time series with a unit root, Journal of the American Statistical Association, 74(366): 427-431. 
(Engle and Granger two step, Johansen and Jueslius and the ARDL model). The initial empirical results also reveal that, in the long run, there is a positive and statistically significant relationship between the financial development, government expenditure per capita on education, trade openness and economic growth. This finding is empirically in agreement with the findings of King and Levine (1993a), Demirguc-Kunt and Levine (1996), Levine (1997), Odedokun (1996), Hsu and Lin (2000), Anwar and Nguyen (2009), Schultz (1961), Psacharopoulos (1994), Vamvakidis (2002) and Harrison (1996), who found positive and statistically significant relationships between financial development and economic growth, and between human capital and economic growth, and between openness and economic growth, respectively. Causality results also support bidirectional causality in terms of the relationship between human capital, openness and economic growth in Saudi Arabia. The finding for this model is therefore consistent with empirical evidence in the literature which indicates that the direction of causality, between financial development and economic growth in developing countries, has a supply-leading causality pattern of development rather than a demandfollowing one. Moreover, this finding is inconsistent with some studies such as Hassan and Islam (2005) who do not find any causal relationship between financial development and growth, and between trade openness and growth. It is concluded that the human capital indicator only affects economic growth in the long-run. These findings may be reflecting the nature of this kind of investment (human capital), which take times for its effect to show up in the economy.

Based on the findings of this paper, the policy implication is that the Saudi government should develop the financial sector even more and carry out the necessary procedures to strengthen the relationship between the financial sector and the real economy. 
is significant. In the government expenditure on education per capita Equation 17, all variables have effect on the government expenditure on education per capita, except openness and the ECT (-1) is also insignificant. Finally, in the openness equation all variables do not affect openness, with real GDP being the only exception, and ECM (-1) is insignificant. Table 13 suggests that there is unidirectional causality between credit to the private sector and economic growth. The direction of causality is therefore running from credit to the private sector to economic growth in line with supply-leading hypothesis. The results also indicate that there is bidirectional causality between government expenditure on education per capita and economic growth at $1 \%$ and $10 \%$ respectively, and between openness and economic growth at 1 and 5\% respectively.

Table (13). Granger Causality based on the VECM (2 lags).

\begin{tabular}{|l|c|c|c|c|c|}
\hline $\begin{array}{c}\text { Dependent } \\
\text { Variable }\end{array}$ & $\Delta \mathbf{L Y}$ & $\Delta$ LCPSR & $\begin{array}{c}\Delta \text { LEDUEX } \\
\text { PPC }\end{array}$ & $\begin{array}{c}\Delta \text { LOPEN } \\
\text { NESSR }\end{array}$ & $\begin{array}{c}\text { ECT (-1) } \\
{[\mathbf{t}-\text { stat] }}\end{array}$ \\
\hline \multicolumn{7}{|c|}{ Chi-sq (Wald Statistics) (Prob) } \\
\hline \multirow{2}{*}{$\Delta \mathrm{LY}$} & & $\begin{array}{c}11.362^{*} \\
(0.003)\end{array}$ & $\begin{array}{c}4.823^{* * *} \\
(0.090)\end{array}$ & $\begin{array}{c}40.932^{*} \\
(0.000)\end{array}$ & -0.303 \\
& & & 1.420 & $17.332^{*}$ & 0.403 \\
\multirow{2}{*}{$\Delta$ LCPSR } & 0.541 & & $(0.492)$ & $(0.000)$ & {$[3.301]$} \\
\hline \multirow{2}{*}{$\Delta$ LEDUEXPPC } & $36.189^{*}$ & $4.729 * * *$ & & 0.159 & 0.013 \\
& $(0.000)$ & $(0.094)$ & & $(0.923)$ & {$[0.082]$} \\
\hline \multirow{2}{*}{$\Delta$ LOPENNESSR } & $7.269^{* *}$ & 0.787 & 3.607 & & -0.205 \\
& $(0.026)$ & $(0.675)$ & $(0.165)$ & & {$[-1.351]$} \\
\hline
\end{tabular}

$*, * *$ and $* * *$ indicate the rejection of the null hypothesis of non-stationary at $1 \%, 5 \%$ and $10 \%$ significant level, respectively.

\section{Conclusion}

This paper contributes by examining the relationship between finance and growth in the presence of a human capital indicator as well as trade openness. Time series co-integration tests and causality tests were examined. This was carried out to explore the role of financial development on economic growth when we add human capital and trade openness indicators as control variables in our model. The empirical results suggest that there is a long-run equilibrium relationship between the financial development indicator, human capital, openness and economic growth in Saudi Arabia, according to all co-integration tests 
We re-specify the ARDL model by dropping the insignificant variables. As a result, we estimate the following reduced ARDL model (Parsimonious ARDL $(1,1,1,1))$ :

$\Delta \ln \mathrm{Y}_{\mathrm{t}}=\alpha_{0}+\alpha_{2} \Delta \ln$ CPSR $_{\mathrm{t}-\mathrm{i}}+\alpha_{3} \Delta \ln$ OPENESS $_{\mathrm{t}-\mathrm{i}}+\delta_{1} \ln \mathrm{Y}_{\mathrm{t}-1}+\delta_{2} \ln$ CPSR $_{\mathrm{t}-1}+\varepsilon_{\mathrm{t}}$

The empirical results are reported in Table 12. The results indicate that credit to the private sector has a significant positive impact on economic growth in both the long and short run. In addition, trade openness has a significant positive impact on economic growth in the short run. The results also suggest that the growth of real GDP over time in Saudi Arabia can be explained by the growth of credit to the private sector in both the long and the short run, and the growth of trade openness in the short run. This finding is in line with the literature.

Table (12). ARDL Estimation of Financial Development and Economic Growth (The Parsimonious Model).

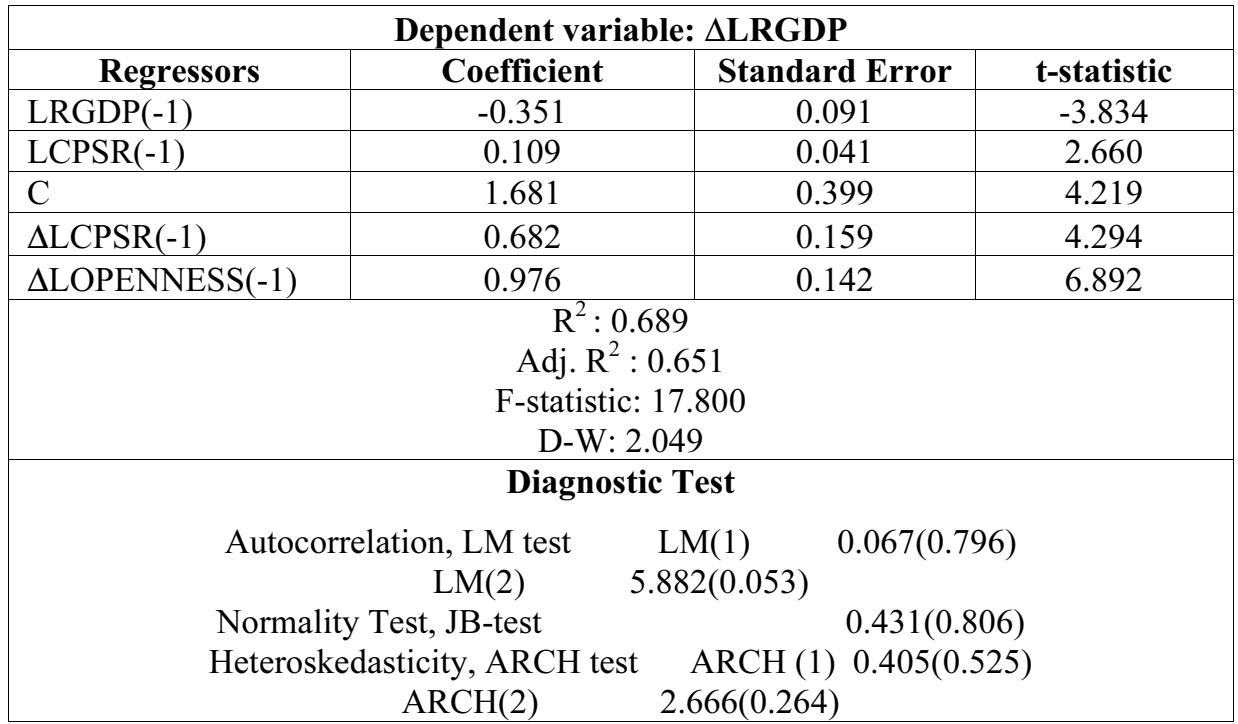

-Numbers in brackets are $p$ values.

\subsection{Granger Causality Tests Results}

Table (13) indicates that all variables could affect GDP. The ECT (-1) in Equation 15 is significant. In the credit to the private sector Equation 16, only openness does affect the credit to the private sector and the ECT(-1) 
where $\Delta$ denotes first difference, $\mathrm{k}=1,2, \alpha_{0}$ is a constant component and $\varepsilon_{t}$ is white noise error, $\ln \mathrm{Y}_{\mathrm{t}}, \ln \mathrm{CPSR}_{\mathrm{t}}$, $\ln$ EDUEXPPC $_{\mathrm{t}} \ln \mathrm{OPENNESS}_{\mathrm{t}}$ as defined in Equation 20. The coefficients of the first difference variables are the short-term parameters, while the long-term elasticities are obtained from estimating Equation 22. Table 11 reports the empirical results of the regression. From the results in Table 11, some of these variables are not significant, particularly the level and first difference of the government expenditure on education per capita, the level of openness and the first difference of real GDP lagged.

Table (11). ARDL Estimation of Financial Development and Economic Growth.

\begin{tabular}{|l|c|c|c|}
\hline \multicolumn{5}{|c|}{ Dependent variable: $\Delta$ LRGDP } \\
\hline Regressors & Coefficient & Standard Error & t-statistic \\
\hline LRGDP(-1) & -0.467 & 0.231 & -2.020 \\
\hline LCPSR(-1) & 0.153 & 0.078 & 1.921 \\
\hline LEDUEXPPC(-1) & 0.036 & 0.113 & 0.319 \\
\hline LOPENNESS(-1) & 0.195 & 0.196 & 0.992 \\
\hline C & 2.013 & 0.536 & 3.757 \\
\hline$\Delta$ LRGDP(-1) & 0.243 & 0.225 & 1.079 \\
\hline$\Delta$ LCPSR(-1) & 0.552 & 0.178 & 3.102 \\
\hline$\Delta$ LEDUEXPPC(-1) & -0.126 & 0.090 & -1.395 \\
\hline$\Delta$ LOPENNESS(-1) & 0.937 & 0.200 & 4.689 \\
\hline \multicolumn{5}{|c|}{$\mathrm{R}^{2}: 0.746$} \\
Adj. $\mathrm{R}^{2}: 0.673$ \\
F-statistic: 10.281 \\
D-W: 1.966 \\
\hline
\end{tabular}

$\mathrm{Y}=\mathrm{RGDP}$

The co-integration test developed by Pesaran et al. (2001), the 'bounds test' approach, suggests analyzing the null hypothesis of no cointegration through a joint significant test of the lagged variables, depending on the familiar Wald test or the F-statistic. The null hypothesis is $\mathrm{H}_{0}: \delta_{1}=\delta_{2}=\delta_{3}=\delta_{4}=0$ against the alternative hypothesis $\mathrm{H}_{1}: \delta_{1} \neq 0, \delta_{2} \neq 0$, $\delta_{3} \neq 0, \delta_{4} \neq 0$. To compute the F-statistic it is required to run the following regression:

$\Delta \ln \mathrm{Y}_{\mathrm{t}}=\alpha_{0}+\alpha_{1} \Delta \ln \mathrm{Y}_{\mathrm{t}-\mathrm{i}}+\alpha_{2} \Delta \ln \mathrm{CPSR}_{\mathrm{t}-\mathrm{i}}+\alpha_{3} \Delta \ln \mathrm{EDUEXPPC}_{\mathrm{t}-\mathrm{i}}+\Delta \ln$ OPENEESS $_{\mathrm{t}-\mathrm{i}}+\delta_{1} \ln \mathrm{Y}_{\mathrm{t}-1}+\delta_{2} \ln$ CPSR $_{\mathrm{t}-1}+\delta_{3} \ln$ EDUEXPPC $_{\mathrm{t}-1}+\delta_{4} \ln$ OPENESS $_{\mathrm{t}-1}+\varepsilon_{\mathrm{t}}$ 
Therefore, there is a long-run relationship among the variables under investigation.

Table (9). ARDL Bounds Test for the Existence of Co-integration.

\begin{tabular}{|l|c|c|c|c|c|c|}
\hline \multicolumn{1}{|c|}{ F- Statistic } & \multicolumn{2}{|c|}{$\begin{array}{c}\text { 10\% Critical } \\
\text { value }\end{array}$} & \multicolumn{2}{c|}{$\begin{array}{c}\text { 5\% Critical } \\
\text { value }\end{array}$} & \multicolumn{2}{|c|}{$\begin{array}{c}\text { \% Critical } \\
\text { value }\end{array}$} \\
\hline & $\mathrm{I}(0)$ & $\mathrm{I}(1)$ & $\mathrm{I}(0)$ & $\mathrm{I}(1)$ & $\mathrm{I}(0)$ & $\mathrm{I}(1)$ \\
\hline $\begin{array}{l}\mathrm{F}_{\mathrm{Y}}(\mathrm{Y} / \mathrm{CPSR}, \text { EDUEXP, } \\
\text { OPENNESS })=10.469 *\end{array}$ & 2.45 & 3.52 & 2.86 & 4.01 & 3.74 & 5.06 \\
\hline
\end{tabular}

Notes: computed F-statistic (Wald test) $=10.469$ (three regressors with lags, $\mathrm{k}=3$ ). The upper and lower bounds were obtained using restricted intercept with no trend. * and ** denote rejecting the null at 1 and $5 \%$ level respectively. The critical values are obtained from Pesaran et al. (2001), Table CI (III).

The test involves estimating the following unrestricted error-correction model (UECM) for the relationship between financial development and economic growth. Since the data are annual, we select 2 for the maximum order of the lags in ARDL model. The next step of the procedure is to estimate the coefficients of the long-run relationship and the associated error correction model (ECM) using the ARDL model. Since the choice of the lag length are essential in assessing the ARDL regression, the test run over 1 and 2 lag lengths in order to determine the optimal lag length. The Schwarz Bayesian Criterion (SBC) and Akaike information criterion (AIC) both select lag length of 1 , see Table 10.

Table (10). Lag Order Selection based on AIC and SC Criteria.

\begin{tabular}{|c|c|c|}
\hline Lag & AIC & SBC \\
\hline 1 & $-1.406526^{*}$ & $-1.014681^{*}$ \\
\hline 2 & -0.678707 & -0.282827 \\
\hline
\end{tabular}

* indicates significance at $1 \%$ level (rejection of the null hypothesis at $1 \%$ ).

To apply the bounds test procedure, the error correction version of the $\operatorname{ARDL}(1,1,1,1)$ is given by:

$\Delta \ln \mathrm{Y}_{\mathrm{t}}=\alpha_{0}+\sum_{i=1}^{k} \alpha_{1} \Delta \ln \mathrm{Y}_{\mathrm{t}-\mathrm{i}}+\sum_{i=0}^{k} \alpha_{2} \Delta \ln \operatorname{CPSR}_{\mathrm{t}-\mathrm{i}}+\sum_{i=0}^{k} \alpha_{3} \Delta \ln$ EDUEXPPC $_{\mathrm{t}-\mathrm{i}}+\sum_{i=0}^{k} \alpha_{4} \Delta \ln$ OPENNESS $_{\mathrm{t}-1}+\delta_{1} \ln \mathrm{Y}_{\mathrm{t}-1}+\delta_{2} \ln$ CPSR $_{\mathrm{t}-1}+$ $\delta_{3} \ln$ EDUEXPPC $_{\mathrm{t}-1}+\delta_{4} \ln$ OPENNESS $_{\mathrm{t}-1}+\varepsilon_{\mathrm{t}}$ 
It is concluded that the model passes these standard diagnostic tests, except the stability test. However, plots of CUSUM and CUSUMSQ statistics show no evidence of instability of the estimated ECM (see Fig. 2).

Table (7). Diagnostic Test for the Residual Statistics.

\begin{tabular}{|l|c|c|}
\hline \multicolumn{1}{|c|}{ Statistics } & Estimated Value & Probability \\
\hline Normality ( Jarque-Bera) & 1.616 & 0.446 \\
\hline Breusch-Godfrey Serial Correlation LM Test & {$[1]: 0.000$} & 1.000 \\
& {$[2]: 0.172$} & 0.918 \\
\hline Arch Test & {$[1]: 0.832$} & 0.362 \\
& {$[2]: 0.027$} & 0.363 \\
\hline Ramsey Reset Test & {$[1]: 11.570$} & 0.001 \\
& {$[2]: 15.969$} & 0.000 \\
\hline
\end{tabular}

Table (8) reports the results of co-integration test. Table (8) indicates that the residuals attained from the regression of output on credit to the private sector, government expenditure on education per capita, and openness, are stationary at (1\%) level of significance. This result suggests that there is a long-run equilibrium relationship between the financial development indicator, government expenditure on education per capita, openness and output in Saudi Arabia (according to the Engle and Granger two step method).

Table (8). Results of Unit Root Test on the Residual of Equation 3.

\begin{tabular}{|c|c|c|c|c|c|c|}
\hline & \multicolumn{2}{|c|}{ ADF test } & \multicolumn{2}{|c|}{ PP test } & \multicolumn{2}{|c|}{ DF-GLS test } \\
\hline & $\mathrm{C}$ & $\mathrm{C} \& \mathrm{~T}$ & $\mathrm{C}$ & $\mathrm{C} \& \mathrm{~T}$ & $\mathrm{C}$ & C\&T \\
\hline & $-5.619 *(0)$ & $-5.531 *(0)$ & $-5.619 *(0)$ & $-5.531 *(0)$ & $-5.014 *(0)$ & $-5.499 *(0)$ \\
\hline \multicolumn{7}{|c|}{ Critical values } \\
\hline & \multicolumn{3}{|c|}{$\mathrm{C}$ but no $\mathrm{T}$} & \multicolumn{3}{|c|}{$C \& T$} \\
\hline $1 \%$ & \multirow{2}{*}{\multicolumn{3}{|c|}{$\frac{-4.682}{30.66}$}} & \multirow{2}{*}{\multicolumn{3}{|c|}{$\begin{array}{l}-5.174 \\
-4.436\end{array}$}} \\
\hline $5 \%$ & & & & & & \\
\hline $10 \%$ & \multicolumn{3}{|c|}{$\frac{-3.900}{-3.614}$} & \multicolumn{3}{|c|}{-4.073} \\
\hline
\end{tabular}

Critical values obtained from MacKinnon 1991. * indicates significance at $1 \%$ level (rejection of the null hypothesis at $1 \%$ ). $\mathrm{C}$ and $\mathrm{T}$ denote constant and trend respectively.

\subsection{Autoregressive Distributed Lag (ARDL) Model Test Results}

The long-run relationship between financial development, human capital indicator, and economic output may be specified as shown in Equation 21. Table 9 shows the results of the ARDL test for the existence of cointegration. The F-statistic 10.469 is above the $1 \%$ critical value bounds [3.74-5.06], i.e. the null hypothesis of no co-integration can be rejected. 
Table (6) estimates the error correction (EC) model. It is apparent that the coefficient of the error term for the economic growth equation is statistically significant and negative, as expected. The coefficients of ECM (-1) indicates that adjustment is faster; $(77 \%)$ of the previous year's disequilibrium in GDP from its equilibrium path will be corrected in the current year. The independent variables explain around $(68 \%)$ of the variation in the GDP. A (1\%) increases in growth rate of credit to the private sector increase the growth rate of real GDP by around $(0.3 \%)$. Similarly, a $(1 \%)$ increase in the growth rate of openness lagged one period results in a $(0.7 \%)$ rise in the growth rate of real GDP. There is no serial autocorrelation, if one employs the Durbin Watson statistic, although this statistic is not reliable in this context (see however the LM tests for serial in Table 8).

Table (5). Engle and Granger Long-Run Regression (1970-2008).

\begin{tabular}{|l|c|c|c|c|}
\hline \multicolumn{5}{|l|}{ The dependent variable is LRGDP } \\
\hline Variable & Coefficient & Std. Error & t-Statistic & Prob. \\
\hline C & 2.50978 & 0.316364 & 7.933203 & 0.000 \\
\hline LCPSR & 0.323953 & 0.03345 & 9.684795 & 0.000 \\
\hline LEDUEXPPC & 0.326094 & 0.054586 & 5.973906 & 0.000 \\
\hline LOPENNESS & 0.525082 & 0.157967 & 3.324004 & 0.002 \\
\hline $\mathrm{R}^{2}=0.942$ & $\mathrm{R}^{2} \mathrm{Adj}=0.937$ & $\mathrm{D}-\mathrm{W}=1.821$ \\
\hline
\end{tabular}

Table (6). Error Correction Model Results by Engle-Granger Two Step Method.

\begin{tabular}{|l|c|c|c|c|}
\hline Dependent variable: $(\boldsymbol{\Delta L R G D P})$ \\
\hline Variable & Coefficient & Std. Error & t-Statistic & Prob. \\
\hline DLRGDP(-1) & 0.645345 & 0.148394 & 4.348858 & 0.0001 \\
\hline DLCPSR & 0.263769 & 0.118038 & 2.234609 & 0.0323 \\
\hline DLOPENNESS(-1) & 0.656555 & 0.161255 & 4.071522 & 0.0003 \\
\hline ECM1(-1) & -0.77257 & 0.188919 & -4.08939 & 0.0003 \\
\hline $\mathrm{R}^{2}=0.679$ & $\mathrm{R}^{2}$ Adj. $=0.651$ & D-W $=1.957$ \\
\hline
\end{tabular}

In order to further justify the error correction model, we employed different diagnostic tests. Four of them are reported. They are: the Normality test, Breusch-Godfrey Serial correlation LM test, and an ARCH test. The last one is a stability test: the Ramesy's RESET test. The results are presented in Table 7 below. 
Table (4). Dickey-Fullers; Generalized Least Squares Unit Root Test.

\begin{tabular}{|c|c|c|c|c|c|c|}
\hline \multicolumn{6}{|c|}{ Null Hypothesis: Variable is not-Stationary } & \multirow[b]{3}{*}{ Decision } \\
\hline \multicolumn{6}{|c|}{ DF: GLS } & \\
\hline \multicolumn{2}{|c|}{ Variables } & $\begin{array}{c}\text { Level } \\
\text { (C) }\end{array}$ & $\begin{array}{c}\text { Level } \\
\text { With C } \\
\text { and trend } \\
\text { (T) }\end{array}$ & $\begin{array}{c}\text { First } \\
\text { differences } \\
\text { ( C ) }\end{array}$ & $\begin{array}{c}\text { First } \\
\text { differences } \\
(\mathrm{C} \& \mathbf{~} \mathbf{)}\end{array}$ & \\
\hline \multicolumn{2}{|l|}{ LRGDP } & $0.036(0)$ & $-2.010(0)$ & $-5.038 *(0)$ & $-5.649 *(0)$ & $\mathrm{I}(1)$ \\
\hline \multicolumn{2}{|l|}{ LCPSR } & $0.289(1)$ & $-1.994(1)$ & $-3.984 *(0)$ & $-4.149 *(0)$ & $\mathrm{I}(1)$ \\
\hline \multicolumn{2}{|c|}{ LEDUEXPPC } & $-0.462(1)$ & $-1.681(1)$ & $-3.411 *(0)$ & $-4.391 *(0)$ & $\mathrm{I}(1)$ \\
\hline \multicolumn{2}{|c|}{ LOPENNESS } & $-1.270(1)$ & $-1.231(1)$ & $-4.746 *(1)$ & $-9.006 *(0)$ & $\mathrm{I}(1)$ \\
\hline \multicolumn{6}{|c|}{ Critical Value } & \\
\hline \multirow{3}{*}{$\begin{array}{l}\text { Signific } \\
\text { ance } \\
\text { level }\end{array}$} & $1 \%$ & -2.627 & -3.770 & -2.629 & -3.770 & \\
\hline & $5 \%$ & -1.950 & -3.190 & -1.950 & -3.190 & \\
\hline & $10 \%$ & -1.611 & -2.890 & -1.611 & -2.890 & \\
\hline
\end{tabular}

Notes: $\mathrm{LRGDP}=\log$ of real DGP, $\mathrm{LCPSR}=\log$ of credit to the private sector, $\mathrm{LEDUEXPPC}=\log$ of government expenditure per capita on education and LOPENNESS $=\log$ of trade openness. Numbers in the brackets are lag lengths. ${ }^{*}, *$ and $* * *$ indicate the rejection of the null hypothesis of non-stationary at $1 \%, 5 \%$ and $10 \%$ significant level, respectively.

\subsection{Engle and Granger Two-Step and ECM Results}

The co-integration test of Engle and Granger (1987) is based on estimated OLS residual-base of the co-integration regression. Estimation of the Engle and Granger regression for Equation 21 is as follows:

Based on the high $\mathrm{R}^{2}$ and low standard errors of estimation, the overall fit of the model is good. The Durbin-Watson (D-W) statistic results do not show the presence of (positive) autocorrelation (see Table 5). The empirical results reveal that there is a positive and statistically significant relationship between the financial development indicator, namely credit to the private sector and economic growth at the $1 \%$ level of significance. Similarly, the results show that there is a positive and statistically significant relationship between government expenditure on education per capita, openness and economic growth. In fact, a $1 \%$ increase in credit to the private sector can raise economic growth by $0.3 \%$. Similarly, a $1 \%$ increase in the government expenditure on education per capita, and openness, may increase the economic growth by $0.3 \%$, and $0.5 \%$, respectively. This result is consistent with previous studies discussed earlier, such as King and Levine (1993) and Schultz (1961) and Harrison (1996). 


\section{Empirical Results}

\subsection{Unit Root Tests Results}

In this study we employ augmented Dickey-Fuller and Dickey-FullerGLS tests in order to check the properties of the variables. Table 3 and 4 report tests results respectively. The ADF unit root results show that all variables are non stationary in level with the exception of LEDUEXPPC which is stationary. The DF-GLS unit root tests (see Table 4) suggested that all variables are integrated in order one, I(1) at $1 \% .{ }^{(10)}$ Nieh and Wang (2005) declare that the mixed results among variables indicate that the variables considered may be integrated of different order. In order to compare the differences of conventional and innovation test, despite the noticeably inconsistent results of I(1) and I(0), we now first apply Engle and Granger (1987) and Johansen and Juselius (1990) techniques to test for the long-run equilibrium relationship among variables in our model; and then we use the ARDL approach. ${ }^{(11)}$

Table (3). Augmented Dickey-Fuller Unit Root Test.

\begin{tabular}{|c|c|c|c|c|c|c|}
\hline \multicolumn{6}{|c|}{ Null Hypothesis: Variable is not-Stationary } & \multirow[b]{3}{*}{ Decision } \\
\hline \multicolumn{6}{|l|}{ ADF } & \\
\hline \multicolumn{2}{|c|}{ Variables } & $\begin{array}{l}\text { Level } \\
\text { with } \\
\text { constant } \\
\text { (C) }\end{array}$ & $\begin{array}{c}\text { Level } \\
\text { With C and } \\
\text { trend }(\mathrm{T})\end{array}$ & $\begin{array}{c}\text { First } \\
\text { differences } \\
\text { ( C ) }\end{array}$ & $\begin{array}{c}\text { First } \\
\text { differences } \\
\text { ( C \&T ) } \\
\text { None }\end{array}$ & \\
\hline \multicolumn{2}{|c|}{ LRGDP } & $-2.329(0)$ & $-2.968(0)$ & $-5.620 *(0)$ & $-5.599 *(0)$ & $\mathrm{I}(1)$ \\
\hline \multicolumn{2}{|c|}{ LCPSR } & $1.467(2)$ & $2.145(1)$ & $-4.197 *(0)$ & $-4.179 * *(0)$ & $\mathrm{I}(1)$ \\
\hline \multicolumn{2}{|c|}{ LEDUEXPPC } & $-3.279 * *(1)$ & $-3.214 * * *(1)$ & $-4.418 *(0)$ & $-4.508 *(0)$ & $\mathrm{I}(0)$ \\
\hline \multicolumn{2}{|c|}{ LOPENNESS } & $-1.159(1)$ & $-0.777(1)$ & $-4.714 *(1)$ & $-8.753 *(0)$ & $\mathrm{I}(1)$ \\
\hline \multicolumn{7}{|c|}{ Critical Value } \\
\hline \multirow{3}{*}{$\begin{array}{l}\text { Signifi } \\
\text { cance } \\
\text { level }\end{array}$} & $1 \%$ & -3.616 & -4.219 & -3.621 & -4.227 & \\
\hline & $5 \%$ & -2.941 & -3.533 & -2.943 & -3.537 & \\
\hline & $10 \%$ & -2.609 & -3.198 & -2.610 & -3.200 & \\
\hline
\end{tabular}

Notes: $\mathrm{LRGDP}=\log$ of real DGP, LCPSR $=\log$ of credit to private sector, $\mathrm{LEDUEXPPC}=\log$ of government expenditure on education per capita and LOPENNESSR $=\log$ of trade openness.

Numbers in the brackets are lag lengths. $*, * *$ and $* * *$ indicate the rejection of the null hypothesis of non-stationary at $1 \%, 5 \%$ and $10 \%$ significant level, respectively.

(10) The results of PP unit root tests (not reported here to economise a space, but available upon request from the author) are similar to ADF unit root test results.

(11) The result of Johansen and Juselius (1990) co-integration tests (not reported here to save a space, but available upon request from the author) are similar to EG test results. 
reports. Credit to the private sector, and population data are extracted from International Financial Statistics (IFS). Government expenditure on education obtained from the Ministry of Education and the UNESCO. Statistics Database. Finally, trade openness is obtained from the Saudi Arabian Monetary Agency (SAMA) and the Ministry of Economy and Planning, Achievements of the development plans, Facts and Figures, issue 25 (1970-2008).

Descriptive statistics and correlation matrix over the whole sample are summarized in Table 1 and 2 respectively. The correlation matrix is presented in Table 2 which shows high positive correlation between LEDUEXPPC and LCPSR, while the correlation between trade openness and other variables is negative. The positive and negative trends in the data can be noticed from Fig. (1).

Table (1). Summary Statistics: 1970-2008.

\begin{tabular}{|l|c|c|c|c|}
\hline & LRGDP & LCPSR & LEDUEXPPC & LOPENNESS \\
\hline Mean & 6.142 & 4.202 & 7.376 & -0.256 \\
\hline Median & 6.253 & 4.437 & 7.511 & -0.274 \\
\hline Maximum & 7.315 & 6.442 & 8.335 & 0.222 \\
\hline Minimum & 4.351 & 1.749 & 4.753 & -0.571 \\
\hline Std. Dev. & 0.653 & 1.322 & 0.783 & 0.1801 \\
\hline Skewness & -0.790 & -0.417 & -1.973 & 0.419 \\
\hline Kurtosis & 3.974 & 2.341 & 6.347 & 2.683 \\
\hline Jarque-Bera & 5.593 & 1.837 & 43.503 & 1.306 \\
\hline Probability & 0.061 & 0.399 & 0 & 0.521 \\
\hline Sum & 239.530 & 163.888 & 287.649 & -9.986 \\
\hline Sum Sq. Dev. & 16.211 & 66.407 & 23.281 & 1.241 \\
\hline Observations & 39 & 39 & 39 & 39 \\
\hline
\end{tabular}

Y= LRGDP

Table (2). Correlation Coefficient Matrix : 1970-2008.

\begin{tabular}{|l|c|c|c|c|}
\hline & & LCPSR & LEDUEXPPC & LOPENNESS \\
\hline & & & & \\
\hline LCPSR & & 1 & 0.764 & -0.260 \\
\hline LEDUEXPPC & & & 1 & -0.033 \\
\hline LOPENNESS & & & & 1 \\
\hline
\end{tabular}


We can re-write Equation 19 as follows: ${ }^{(9)}$

$$
\mathrm{Y}_{\mathrm{t}}=\mathrm{f}\left(\mathrm{FD}_{\mathrm{t}}, \mathrm{EDUEXPPC}_{\mathrm{t}}, \text { OPENNESS }_{\mathrm{t}}\right)
$$

where $\mathrm{Y}_{\mathrm{t}}$ is real gross domestic product, $\mathrm{FD}_{\mathrm{t}}$ is the financial development indicator, namely credit to private sector as a percentage of GDP (CPSR). EDUEXPPC $_{t}$ is the government expenditure on education divided by population and OPENNESS $S_{t}$ is the total exports plus total imports over GDP. On the basis of this general model the following linear equation is estimated using the EG method:

$\ln \mathrm{Y}_{\mathrm{t}}=\alpha_{0}+\alpha_{1} \ln \mathrm{CPSR}_{\mathrm{t}}+\alpha_{2} \ln$ EDUEXPPC $_{\mathrm{t}}+\alpha_{3} \ln \mathrm{OPENNESS}_{\mathrm{t}}+\varepsilon_{\mathrm{t}}$

where $\alpha_{0}$ is a constant, $\alpha_{1}, \alpha_{2}, \alpha_{3}$ are the coefficients and $\varepsilon_{\mathrm{t}}$ is a random error term. The expected signs of the explanatory variables are positive. See Table 5 for full results from estimation of Equation 21.

\subsubsection{Data}

Annual data covering the period 1970-2008 is used for this model. The variables represent financial development indicator, namely credit to the private sector as a percentage of GDP (CPSR), and two control variables, namely government expenditure on education per capita (EDUEXPPC), to measure human capital, and trade openness (OPENNESS). All variables are expressed in national currency. Gross domestic product extracted from the Saudi Arabian Monetary Agency (SAMA), annual

(9) We have used real GDP per capita as the dependent variable and we have tried the following variables as independent variables: credit to the private sector ratio (CPS/GDP), broad money supply ratio (M3R/GDP), bank deposits ratio (BD/GDP), financial savings ratio (FS/GDP), investment ratio (INV/GDP), INV per capita, OPENNESS, secondary school enrolment (SEC), ratio of government expenditure on education (EDUEXP/GDP), EDUEXP per capita (PC), labour force (LFO), labour force per capita LFO/POP, government expenditure ratio (GE/GDP) and government consumption/GDP, but the results were not satisfactory. That is, the coefficients of financial development indicators were negative and significant. The coefficient of the human capital indicator (SEC) was also negative and significant (against the economic theory). R2 was also low. The other problem was that the models could not pass the diagnostic tests for most of the above cases. Finally, in some cases, the null hypothesis of no co-integration cannot reject. We have also used non-oil real GDP (NORGDP) as a dependent variable but the result were still unsatisfactory in this case too. 
development indicator"'(Akimov, Wijeweera and Dollery (2009, pp.10001001)). Consequently, we employ four proxies for financial system development to examine the different dimensions of the financial sector. First, following the literature, this model applies the popular variable of credit to the private sector as a ratio of GDP (CPSR). Second, we apply financial savings as a ratio of GDP (FSR). Finally, we use banks deposits as a ratio of GDP (BDR) or broad money supply as a ratio of GDP $(\mathrm{M} 3 \mathrm{R})^{(7)}$. The choice of variables is based on previous studies, such as Tarabelsi (2002), Saci and Holden (2008) and Yay and Oktayer (2009) among others, and the definition of the variables is provided in Table 1A.

In terms of the human capital in this model, we use government expenditure per capita on education. ${ }^{8}$ This indicator is included under the name (EDUEXPPC). It is anticipated that all explanatory variables will emerge positive and significant from the estimation, and an especially, positive relationship between the financial development indicator and economic growth.

In the empirical analysis, we employ dynamic time series methods for linkage between financial development, human capital and economic growth, following earlier literature, such as King and Levine (1993a), Levine (1997), Khan and Senhadji (2000), Trabelsi (2002), Christopoulos and Tsionas (2004), Akimovet al. (2009) and Yay and Oktayer (2009), among others.

The economic literature often suggests the following model of financegrowth nexus:

$$
\mathrm{G}=\mathrm{f}(\mathrm{FD}, \mathrm{CV})
$$

where $\mathrm{G}$ is the economic growth measured by the gross domestic product (GDP) which is a function of FD (set of financial development indicators) and $\mathrm{CV}$ (other control variables believed to be linked to economic growth).

(7) The problem for models with FSR, BDR and M3R - as alternative measures of financial development - was that the estimation results for those models were not satisfactory. Consequently, we dropped those variables from our analysis.

(8) This variable is employed by Jantan and Chen (2005) and Hussain, Chaudhry and Malik (2009). 
variable, rather than not using such past values, all other terms remaining unchanged. According to Engle and Granger (1987) and Granger (1988), if a co-integrating vector exists among variables, then Granger causality exists amongst these variables in at least in one direction.

Granger (1986) and Engle and Granger (1987) provided tests of causality, which take into account the information provided by the cointegrated properties of variables. Following to Sims (1972), the Granger Causality test for the case of two variables $y_{t}$ and $x_{t}$, involves as a first step the estimation of the following VAR model:

$$
\begin{aligned}
& \mathrm{X}_{\mathrm{t}}=\alpha_{0}+\sum_{i=1}^{n} \beta_{i} \mathrm{X}_{\mathrm{t}-\mathrm{i}}+\sum_{j=1}^{n} \gamma_{j} \mathrm{Y}_{\mathrm{t}-\mathrm{j}}+\mathrm{u}_{1 \mathrm{t}} \\
& \mathrm{Y}_{\mathrm{t}}=\gamma_{0}+\sum_{j=1}^{n} \delta_{j} \mathrm{X}_{\mathrm{t}-\mathrm{j}}+\sum_{i=1}^{n} \theta_{i} \mathrm{Y}_{\mathrm{t}-\mathrm{i}}+\mathrm{u}_{2 \mathrm{t}} \\
& \mathrm{X}_{\mathrm{t}=\alpha_{1}} \mathrm{X}_{\mathrm{t}-1}+\alpha_{2} \mathrm{X}_{\mathrm{t}-2}+\ldots+\alpha \mathrm{i} \mathrm{X}_{\mathrm{t}-\mathrm{i}}+\mathrm{u}_{1 \mathrm{t}} \\
& \mathrm{Y}_{\mathrm{t}=} \gamma_{1} \mathrm{Y}_{\mathrm{t}-1}+\gamma_{2} \mathrm{Y}_{\mathrm{t}-2}+\ldots+\gamma_{\mathrm{i}} \mathrm{Y}_{\mathrm{t}-\mathrm{i}}+\mathrm{u}_{2 \mathrm{t}}
\end{aligned}
$$

where is assumed that $\mathrm{u}_{1 \mathrm{t}}$ and $\mathrm{u}_{2 \mathrm{t}}$ are uncorrelated white noise error terms. Equation 15 assumes that current $\mathrm{X}$ is related to past values of itself as well as that $\mathrm{Y}$, and Equation 16 assumes a similar behavior for Y. Equation 15 and Equation 16 are called unrestricted, 17 and 18 restricted. In this study $\mathrm{X}$ denotes an indicator of financial development, $\mathrm{Y}$ denotes economic growth and the subscripts $t$ and $t-i$ denotes the current and lagged values respectively.

\subsection{Model Specification}

We apply the co-integration approaches of Engle and Granger (1987) and the bounds testing approach within the autoregressive distributed lag (ARDL) framework developed by Pesaran et al. (2001). The major advantage of the ARDL method is that it does not require that the indicators in a time series regression equation are integrated of order one and can be implemented regardless of whether the underlying variables are $\mathrm{I}(1)$ or $\mathrm{I}(0)$, or fractionally integrated.

"Since no existing financial system development indicators can fully and accurately capture the complexity and sophistication of the role of financial intermediaries, it is unwise to rely on a single financial 
long-run relationship exists among the variables, the following error correction model is estimated:

$$
\begin{aligned}
& \Delta \ln \mathrm{Y}_{\mathrm{t}}=\alpha_{0}+\sum_{i=1}^{n} \alpha_{1} \Delta \ln \mathrm{Y}_{\mathrm{t}-\mathrm{i}}+\sum_{i=1}^{n} \alpha_{2} \Delta \ln \mathrm{X}_{1 \mathrm{t}-\mathrm{i}}+\sum_{i=1}^{n} \alpha_{3} \Delta \ln \mathrm{X}_{2 \mathrm{t}-\mathrm{i}}+\ldots \\
& +\sum_{i=1}^{n} \alpha_{4} \Delta \ln \mathrm{X}_{\mathrm{kt}-\mathrm{i}}+\gamma \mathrm{ECM}_{\mathrm{t}-1}+\varepsilon_{\mathrm{t}}
\end{aligned}
$$

To ensure the fitness of the model, checking and stability tests are also carried out. The diagnostic tests investigate serial correlation, functional form normality and heteroscedasticity. In addition, Pesaran and Pesaran (1997) suggest using the Brown, Durbin and Evans (1975) stability test or cumulative (CUSUM) and cumulative sum squares (CUSUMSQ) tests in order to examine the stablity of the short-run and long-run coefficients. The CUSUM and CUSUMSQ statistics are updated recursively and plotted against the break points. If the plots of CUSUM and CUSUMSQ statistics stay within the critical bounds of the 5\% level of significance, then the null hypothesis that all coefficients in the given regression are stable cannot be rejected.

\subsection{Granger Causality Tests}

The financial development, human capital and economic growth will also be examined by employing causality tests. The essential advantage of this method is to identify the direction of causality between the variables under consideration. There are three different kinds of causality tests. Namely, Granger causality tests, multivariate causality test and Granger causality test within vector autoregressive (VAR). ${ }^{(6)}$

Causality in econometrics is a bit unlike the concept in daily use; it refers more to the capability of one variable to predict the other. Assume two variables, say $\mathrm{y}_{\mathrm{t}}$ and $\mathrm{x}_{\mathrm{t}}$, influence each other with distributed lags. The relationship between those variables may be captured by a vector autoregressive (VAR) model. In this case it is likely to be that (a) $y_{t}$ causes $\mathrm{x}_{\mathrm{t}}$ (demand-following), (b) $\mathrm{x}_{\mathrm{t}}$ causes $\mathrm{x}_{\mathrm{t}}$ (supply-leading) (c) there is a bi-directional causality between variables, and finally (d) the two variables are independent. Granger (1969) built up a relatively simple test that defined causality as follows: a variable $y_{t}$ is said to Granger-cause $x_{t}$, if $x_{t}$ can be predicted with greater accuracy by using past values of the $y_{t}$

(6) See for instance Erjavec and Cota (2003). 
Equation 18 are the coefficients of the one lagged explanatory variables (multiplied by a negative sign) divided by the coefficient of the one lagged dependent variable, i.e., - $\left(\delta_{2} / \delta_{1}\right),-\left(\delta_{3} / \delta_{1}\right)$, and - $\left(\delta_{4} / \delta_{1}\right)$ respectively. For the above model, the null hypothesis is $\mathrm{H}_{0}: \delta_{1}=\delta_{2}=\delta_{3}=$ $\delta_{4}=0$ and is tested against the alternative $\mathrm{H}_{1}: \delta_{1} \neq 0, \delta_{2} \neq 0, \delta_{3} \neq 0, \delta_{4} \neq 0$. The recommended statistic is the F-statistic for the joint significance of $\delta_{1}, \delta_{2}$, $\delta_{3}$, and $\delta_{4}$. To compute the F-statistic it is required to run the following regression:

$$
: \Delta \ln \mathrm{Y}_{\mathrm{t}}=\alpha_{0}+\alpha_{1} \Delta \ln \mathrm{Y}_{\mathrm{t}-\mathrm{i}}+\alpha_{2} \Delta \ln \mathrm{X}_{1 \mathrm{t}-\mathrm{i}}+\alpha_{3} \Delta \ln \mathrm{X}_{2 \mathrm{t}-\mathrm{i}}+\Delta \ln \mathrm{X}_{\mathrm{kt}-\mathrm{i}}+\varepsilon_{\mathrm{t}}
$$

Pesaran et al. (2001) have established that, under the null hypothesis of no co-integration and regardless of the degree of integration, the obtained F-statistic is non-standard. They developed two bounds of critical values for the different model specifications: the upper bound applies when all variables are integrated of order one, I (1), and the lower bound applies when all the variables are stationary, I (0). If the calculated F-statistic, for a selected level of significance, exceeds the upper critical bound then the null hypothesis of no co-integration is rejected. If the F- statistic is lower than the lower bound, then the null hypothesis cannot be rejected. If, however, the calculated F-statistic lies between the lower and the upper bounds, conclusive inference may not be made.

As Pesaran et al. (2001) note, a shortcoming of their method is that it is not appropriate in situations where there are more than one cointegrating vectors. We test the null hypothesis of no co-integration by means of the F-test. After confirmation of the existence of a long-run relationship among the variables, the long-run and short-run models can be derived using information criteria such as the Schwartz Bayesian criterion, Akaike information criteria and Hannan-Quinn criterion. In other words, the first step in the ARDL bounds test approach is to estimate Equation 12 by ordinary least squares (OLS). In the second step, we estimate the long-run relationship using the selected ARDL model through AIC and SBC and HQ. Finally, when the long-run relationship exists among the variables, then there is an error correction representation. Therefore, the following error correction model is estimated. The error correction model results reveal the speed of adjustment back to long-run equilibrium after a short-run shock. If a 
an unrestricted error correction model (UECM). Finally, the general to specific modeling technique of Hendry (1995) is employed to obtain a parsimonious error corerecion model (see Ang (2009), pp. 88- 92).

We follow Pesaran et al. (2001) and consider the following general $\operatorname{ARDL}(\mathrm{q}, \mathrm{p})$ model:

$$
\begin{aligned}
& \mathrm{y}_{\mathrm{t}}=\alpha_{0}+\alpha_{1} \mathrm{t}+\sum_{i=1}^{p} \phi_{\mathrm{i}} \mathrm{y}_{\mathrm{t}-\mathrm{i}}+\dot{\beta} \mathrm{X}_{\mathrm{t}}+\sum_{i=0}^{q-1} \beta_{1} * \Delta \mathrm{X}_{\mathrm{t}-\mathrm{i}}+\mathrm{u}_{\mathrm{t}} \\
& \Delta \mathrm{x}_{\mathrm{t}}=\mathrm{P}_{1} \Delta \mathrm{x}_{\mathrm{t}-1}+\mathrm{P}_{2} \Delta \mathrm{x}_{\mathrm{t}-2}+\ldots+\mathrm{P}_{\mathrm{s}} \Delta \mathrm{x}_{\mathrm{t}-\mathrm{s}}+\varepsilon_{\mathrm{t}}
\end{aligned}
$$

where $\mathrm{x}_{\mathrm{t}}$ is the $\mathrm{K}$-dimensional $\mathrm{I}(1)$ variables that are not co-integrated among themselves, $\mathrm{u}_{\mathrm{t}}$ and $\varepsilon_{\mathrm{t}}$ are serially uncorrelated disturbances with zero means and constant variance-covariance, and $\mathrm{P}_{\mathrm{i}}$ are the $(\mathrm{k} \times \mathrm{k})$ coefficients matrices such that the vector autoregressive process in $\Delta \mathrm{x}_{\mathrm{t}}$ is stable.

Pesaran, Shin and Smith (1996) suggest the unrestricted ECM for testing co-integration between series and revealed this method is suitable for small samples. ${ }^{(5)}$ Therefore, the ARDL model is modified to an error correction model. The bounds test procedure and the error correction model tests are performed based on the unrestricted error correction model (UECM) as below:

$$
\begin{aligned}
& \Delta \ln \mathrm{Y}_{\mathrm{t}}=\alpha_{0}+\sum_{i=1}^{n} \alpha_{1} \Delta \ln \mathrm{Y}_{\mathrm{t}-\mathrm{i}}+\sum_{i=1}^{n} \alpha_{2} \Delta \ln \mathrm{X}_{1 \mathrm{t}-\mathrm{i}}+\sum_{i=1}^{n} \alpha_{3} \Delta \ln \mathrm{X}_{2 \mathrm{t}-\mathrm{i}}+\ldots+ \\
& \sum_{i=1}^{n} \alpha_{4} \Delta \ln \mathrm{X}_{\mathrm{kt}-\mathrm{i}}+\delta_{1} \ln \mathrm{Y}_{\mathrm{t}-1+\delta_{2}} \ln \mathrm{X}_{1 \mathrm{t}-1}+\delta_{3} \ln \mathrm{X}_{2 \mathrm{t}-1}+\delta_{4} \ln \mathrm{X}_{\mathrm{k} \mathrm{t}-1+\varepsilon_{\mathrm{t}}}
\end{aligned}
$$

where $\mathrm{k}$ is the number of variables, $\Delta$ denotes first difference, $\alpha_{0}$ is a constant and $\varepsilon_{\mathrm{t}}$ is white noise error. The variables can be distinguished by estimating each equation considering each of the variables as a dependent variable. Since we have annual observations, we select $n=2$ for the maximum order of lags in the ARDL model, in all cases, and carry out the estimation over the span of study.

The coefficients of the first difference variables are the short-term parameters, while the long-term elasticities are derived according to Bardsen (1989), the long-run elasticities obtained from estimating

(5) See for example Ghorbani and Motallebi (2009). 
and Ang (2009) declare that in the presence of $I(2)$ variables the computed F-statistics provided by Pesaran et al. (2001) are not valid due to the fact that they are calculated on the assumption that the variables are $\mathrm{I}(0)$ or I(1). As a result, unit root tests in the ARDL model may still be necessary to ensure that none of the variables is integrated of order 2 or beyond.

Bounds test procedure is robust for co-integration analysis with small sample study (Pattichis 1999; Mah 2000 and Tang and Nair 2002). The ARDL model can distinguish between dependent and explanatory variables. (I.e. it avoids the problem of endogeneity); (Afzel et al. 2010). Estimation is possible ever when explanatory variables are endogenous (Alam and Quazi, 2003). UECM is likely to have better statistical properties than the two-step Engle and Granger (1987) method because, unlike the Engle and Granger (1987) method, the UECM does not push the short-term dynamics into the residual terms. This model also removes problems associated with the omitted variables and autocorrelation (Afzel et al. 2010).

This process which depends on the estimation of an unrestricted error correction model (UECM) is preferred to the common Engle and Granger two step (1987) method and Johansen (1988) and Johnson and Juseliues (1990) which may not be appropriate when the sample size is too small. The UECM test is quite likely to have better statistical properties since it does not push the short-term dynamics into the residual term as in the case of the Engle and Granger two-step (EG) method (see Pattichis (1999), Narayan and Smith (2005) and Odhiambo (2010)). ${ }^{(4)}$

\subsubsection{ARDL Procedure}

The testing procedure contains four steps: first, investigate the integration properties of each variable to employ the co-integration tests. It is essential to ensure that variables under investigation are not integrated at an order higher than one as we mentioned above. Second, test for cointegration utilizing the ARDL bounds test, which includes both a t-test and an F-test. Third, if there is co-integration between the series under consideration, the third phase is to obtain a long-term model employing

(4) Hoque and Yusop (2010, pp. 43-44) discuss additional advantages of the ARDL bounds test approach. 
have a long-run equilibrium relationship between the variables under consideration. Since the variables under investigation are integrated of degree one, I(1), the co-integration test is carried out to determine the long-run relationship between these variables. Engle and Granger (1987) compared different tests and recommended the co-integration ADF (CADF) test. They supplied critical values depended on Monte Carlo simulations for the case of the just one regressor. Engle and Yoo (1987) expand those tables to the case of more than one regressor, and Mackinnon (1991) has the most complete tables available so far. In addition, the existence of a causality relationship is at least in one direction; Granger (1988). However, the Engle and Granger method is considered appropriate for two time series with large sample sizes.

\subsubsection{Error Correction Model Estimation (ECM)}

The Engle-Granger representation concept, Engle-Granger (1987), shows that if two series are co-integrated then an ECM will represent them most efficiently and, additionally, the dynamic requirement will include any other dynamic terms involving the partial adjustment model. According to the Granger representation theorem, if variables are co-integrated then an error correction model (ECM) exists, which joins the long-run relationship with the short-run dynamics of the model. The acceptance of co-integration between two series implies that there exists a long-run relationship between them. Diagnostic tests are carried out to check the appropriateness of the estimated models. These comprise: Lagrange Multiplier test of residual serial correlation, Ramsey's RESET test for specification error, and White test for heteroscedasticity based on the regression of squared residuals on squared fitted values, and the JacqueBera test of normality.

\subsubsection{The ARDL Bounds Testing Approach}

In this paper we also use the relatively new co-integration methodology developed via the autoregressive distributed lag (ARDL) approach, suggested by Pesaran and Shin $(1995,1999)$ and extended by Pesaran et al. (2001) to test for the existence of one long-run relationship (cointegration). The problems related with unit root tests support the use of the bounds testing process suggested by Pesaran et al. (2001) which is applicable irrespective of whether the underlying regressors are purely I(0), purely I(1) or mutually co-integrated. However, Ouattara (2004a) 


\subsubsection{Engle and Granger (1987)}

The most well recognized test, proposed by Engle and Granger (1987), is often referred to simply as EG. The EG co-integration test relies on estimated residuals from OLS of the co-integration regression. The estimated residuals are tested for the existence of a unit root (stationratiy) in the autoregressive representation. If these residuals are found to be stationary, then the series are co-integrated. Consider the following general linear co-integration model

$$
Y_{t}=\beta^{\prime} X_{t}+e_{t}
$$

where $Y_{t}$ represents dependent variable and $X_{t}$ represents explanatory variables. Subsequently the residuals from the regression are checked for stationary, $\hat{e}_{t}=Y_{t}-\beta^{\prime} X_{t}$. From Equation 4.17, the estimated residuals are found by OLS regression as follows:

$$
\hat{\mathrm{e}}_{\mathrm{t}}=\mathrm{y}_{\mathrm{t}}-\alpha_{0}-\sum_{i=1}^{m-1} \alpha_{i} \mathrm{x}_{\mathrm{it}}, \mathrm{t}=1,2, \ldots, \mathrm{T}
$$

The augmented Dickey-Fuller model is

$$
\Delta \hat{\mathrm{e}}_{\mathrm{t}}=\alpha \hat{\mathrm{e}}_{\mathrm{t}-1}+\sum_{i=1}^{n} \gamma_{i} \Delta \hat{\mathrm{e}}_{\mathrm{t}-1}+\xi_{\mathrm{t}} \quad \mathrm{t}=1,2, \ldots, \mathrm{T}
$$

$\xi_{t}$ are serially uncorrelated. The ADF test statistic for the null hypothesis of no co-integration is the $t$-statistic for $\alpha=0$ in Equation 7. Since the ADF is applied on an estimated residual the table of the critical values provide by Fuller (1976) cannot be utilized. Instead, Mackinnon (1991) has tabulated the critical values for the ADF $t$-statistic by estimating response surface regressions as follows:

$$
\mathrm{C}(\mathrm{P})=\beta_{\infty}+\beta_{1} \mathrm{~T}^{-1}+\beta_{2} \mathrm{~T}^{-2}
$$

where $\mathrm{T}$ is the sample size and $\mathrm{C}(\mathrm{p})$ are the critical values for a test at the $p$ percent level.

Engle and Granger suggest a two-step method to examine cointegration between two series. The first step is to run the co-integration regression (Equation 6) by Ordinary Least Squares (OLS). If the ADF and DF: GLS unit root tests for residuals suggest that the residuals are stationary, $\mathrm{I}(0)$, then, there is co-integration between $\mathrm{Y}_{\mathrm{t}}$ and $\mathrm{X}_{\mathrm{t}}$, i.e., they 


\subsection{Co-integration Approaches}

Co-integration methods are considered one of the main improvements in modeling economic time series. The co-integration test was first introduced by Engle and Granger (1987) and then developed and modified by Stock and Watson (1988), Johansen (1988) and Johansen and Juselius (1990) and more recently by Pesaran et al. (2001). The test is very useful in investigating the long-run equilibrium between variables. A significant concern in co-integration is examining if the integrated series are co-integrated.

There are various methods for examining the co-integration analysis in the finance-growth nexus. The popular approaches are: the wellknown residual based approach proposed by Engle and Granger (1987), and the maximum likelihood based approach proposed by Johansen and Juselius (1990). In other words, the former relied on a single equation static regression (two variables) and the other depends on system of multiple equations (more than two variables). One of the most frequently employed tests in the single-equation approach is the residual based test, where the null hypothesis of no co-integration is tested against the alternative that the relation is co-integrated.

The first test utilizing this method was suggested by Engle and Granger (1987). They illustrate a number of tests for the existence of a unit root in the residuals from Ordinary Least Squares (OLS) estimation of the co-integrating regression. They recommended the augmented Dickey-Fuller test. The two non-stationary variables with the same order of integration could be co-integrated if there exists some linear combination of the variables that can be verified as stationary, i.e., $\mathrm{I}(0)$. One of the limitations of the tests is that all the variables used in the model might have equal order of integration. The requirement of these co-integration tests is that all variables in the equation must be integrated of order one, I(1). In addition, according to Pesaran and Pesaran (1997), the Engle and Granger (1987) and Johansen and Juselius (1990) tests are inefficient and may lead to contradictory results, when there are more than two I(1) variables under consideration. Subsequently, the ARDL approach to co-integration has become popular as compared to the conventional co-integration tests; Chyuan, (2005, pp. 42-43). 
tested against the alternative hypothesis that $\gamma \prec 0$. The null hypothesis tested is that the concerned series contains a unit root against the alternative hypothesis that the variable is stationary. The decision criteria is that if the $t$ statistic for $\gamma$ is more negative than its $5 \%$ critical values, then the null hypothesis is rejected and contains no unit root. Otherwise, it has a unit root (see Gujarati (2003)).

\subsubsection{The Dickey-Fuller Generalized Least Squares (DF-GLS) Test}

The Dickey-Fuller Generalized Least Squares (henceforth DF-GLS) detrending test as developed by Elliot et al. (1996) is a more powerful test than the Dickey-Fuller test. In the augmented Dickey-Fuller $(1979,1981)$ (ADF) test regression, either a drift or a drift (intercept) and a linear time trend is involved to take account of the deterministic components of data. Eilliot et al. (1996), put forward a modification to the ADF regression in which data are de-trended before the unit root test is carried out. This detrending is done by taking the independent variables out of the data. The following equation is estimated to investigate for a unit root in the variable:

$$
\Delta \sum_{i}^{n} \Delta=\alpha y_{t-1}^{d}+\beta_{\mathrm{t}} \Delta y_{t-1}^{d}+\ldots \ldots . .+\beta_{\mathrm{p}} y_{t-p}^{d}+\mathrm{v}_{\mathrm{t}}
$$

where $\Delta$ is the difference operator, $y_{t}^{d}$ is the generalized least squares detrended value of the variable, $\alpha, \beta_{\mathrm{t}}, \beta_{\mathrm{p}}$ are coefficients to be estimated, and $v_{t}$ the independently and identically distributed error term. The order of integration of variable $\mathrm{y}_{\mathrm{t}}$ is calculated by Eilliot et al., (1996) that boosted the power of the ADF test, and the DF-GLS test that is based on unll hypothesis $\mathrm{H}_{0}: \delta_{0}=0$ in the regression.

Where $y_{t}^{d}$ the de-trended series and null hypothesis of this test is that $\mathrm{y}_{\mathrm{t}}$ has a random walk trend, probably with drift as follows:

$$
y_{t}^{d}=\mathrm{y}_{\mathrm{t}}-\hat{\varphi}_{0}-\hat{\varphi}_{1} \mathrm{t}
$$

Mainly, two hypothesis are suggested, (1) $y_{t}$ is stationary about a linear time trend and (2) it is stationary with a non-zero mean, but with no linear time trend (see for example Shahbaz et al. (2008, pp. 17-18)). 
The co-integration methodology requires that the variables should be integrated of the same order. ${ }^{(2)}$ The number of lags necessary to eliminate residual autocorrelation in the annually data is determined utilizing the Akaike Information Criterion (AIC). All equations which will be tested comprise a drift (intercept) and a deterministic trend term (see Maysami and Koh (2000), Boulila and Trabelsi (2004), Maysami et al. (2004), Adam and Tweneboah (2008), and Virmani (2004)).

\subsubsection{The Augmented Dickey-Fuller (ADF) Test}

The Augmented Dickey-Fuller (ADF) unit root test, Dickey-Fuller (1979), (1981) is the simplest and most widely utilized test for determining the order of integration of time series. The ADF test has been constructed as the adjusted version of the simple Dickey-Fuller (DF) test. ${ }^{(3)}$ The ADF method controls for higher-order correlation by adding lagged difference terms of the dependent variable to the righthand side of the regression in order to eliminate autocorrelation. The three possible regression forms, of the ADF unit root test, are given by the following equations:

$$
\begin{aligned}
& \Delta \mathrm{y}_{\mathrm{t}}=\gamma \mathrm{y}_{\mathrm{t}-1}+\sum_{i=1}^{p-1} \delta \mathrm{y}_{\mathrm{t}-\mathrm{i}}+\mathrm{u}_{\mathrm{t}} \\
& \Delta \mathrm{y}_{\mathrm{t}}=\alpha_{0}+\gamma \mathrm{y}_{\mathrm{t}-1}+\sum_{i=1}^{k} \alpha \Delta \mathrm{y}_{\mathrm{t}-\mathrm{i}}+\mathrm{u}_{\mathrm{t}} \\
& \Delta \mathrm{y}_{\mathrm{t}}=\alpha_{0}+\gamma \mathrm{y}_{\mathrm{t}-1}+\alpha_{2} \mathrm{t}+\sum_{i=1}^{k} \alpha \Delta \mathrm{y}_{\mathrm{t}-\mathrm{i}}+\mathrm{u}_{\mathrm{t}}
\end{aligned}
$$

where $\mathrm{y}_{\mathrm{t}}$ is the time series being tested, in period $\mathrm{t}, \alpha_{0}$ is intercept, $t$ is a linear time trend, $\Delta$ is the first difference of time series, $\mathrm{k}$ is the number of lagged first differences, and $u_{t}$ is a white noise term, disturbance with zero mean and constant variance $\sigma^{2}$, that is, $\left[\mathrm{u}_{\mathrm{t}} \sim \mathrm{NI}\left(0, \sigma^{2}\right)\right]$. The null hypothesis of a unit root and the alternative hypothesis is level stationarity. The difference between the three regressions concerns the presence of the deterministic elements $\alpha_{0}, \alpha_{2} t$. The critical values for the ADF tests are taken from Mackinnon (1996). The augmented DickeyFuller (ADF) test is applied for testing stationarity of all variables utilizing Equation (2), the null hypothesis of a unit root is $\gamma=0$ which is

(2) This condition is not necessary for the ARDL model.

(3) For further details for the simple Dickey-Fuller test see, for instance, Asteriou and Hall (2007). 
relatively small size of our samples. In the second step, we employ cointegration approaches. Namely, Engle and Granger (1987) and ARDL (2001) models to investigate the relationship between the variables under consideration in the long and the short-run. Finally we apply Granger causality testing in order to determine the direction of causality between the variables under investigation.

\subsection{Unit Root Tests}

Econometricians presume that most time series economic data are "nonstationary" (because they increase over time and so do not have a fixed "stationary" mean); Kennedy (2003). "The standard conclusion that is drawn from this empirical evidence is that many or most aggregate economic time series contain a unit root", Kwiatkowski et al. (1992, p.160). Therefore it is required to carry out a pre-testing unit root tests to be sure there is a stationary co-integrating relationship amongst the variables to avoid the problem of spurious regression.

To carry out the co-integration and the causality tests between financial development, human capital and economic growth for Saudi Arabia, in a preliminary step the paper tests whether each variable is stationary or not. In other words, before applying the co-integration and causality tests, a unit root or stationary test should be applied to the data utilizing the augmented Dickey-Fuller test (1979) (ADF), the DickeyFuller Generalized Least Squares (DF-GLS) de-trending test proposed by Elliot, Rothenberg and Stock (ERS) (1996).

In order to determine the time series properties (or the order of integration) of each variable to examine the problem of non-stationary of the data we start with a maximum lag of (2) and pare it down to the appropriate lag by examining the Akaike Information Criterion (AIC). ${ }^{(1)}$

(1) We have also utilized other information criteria such as the Schwarz Information Criterion (SIC) and Hannan-Quinn Criterion (HQC). Most of the time these criteria choose the same lag length. Even for cases with different lag lengths chosen by different criteria, the ADF test results are qualitatively similar. Moreover, AlMamum and Nath (2005, p. 362) declare that 'there is no general rule as to how one chooses the maximum lag length to start with.' Enders (1995, P. 227) indicates that one should 'start with a relatively long lag length'. Some researchers utilize the following rule of thumb: start with a maximum lag length equal to the cubic root of the number of observations (see Al-Mamum and Nath, 2005, p. 362). 
both short and long run. Odhiambo (2010) investigates the dynamic causal relationship between financial development, investment and economic growth using three indicators for financial development in an ARDL framework. The results reveal that, on the whole, economic growth has formidable influence on the financial sector development. The study also finds that there is a distinct unidirectional causal run from economic growth to investment, and that investment Granger-causes financial development.

\subsection{Human Capital and Economic Growth}

Theoretical and empirical studies about the causes of economic growth often pay no attention to human capital as a feature of production. On the other hand, contributions, such as Schultz (1961, 1981), Becker (1962), Vaizey (1962), Harobison (1973) and Razen (1977), has made it evident that both the stock of human capital and the investment in education play an important role in explaining the difference across countries in macroeconomic variables like productivity, income per capita, and the rate of growth. However, the relationship between human capital, especially education, and economic growth, is not new. Schultz (1961) indicated that education contributes directly to the growth of national income by improving the skills and productive capabilities of the labour force.

Previous studies used various indicators to measure human capital. These measures comprise secondary school enrolment and tertiary levels, government expenditure on education, literacy rate and life expectancy rate. In this study we use government expenditure on education per capita as a proxy of human capital. The literature proposes that human capital encourages economic growth, and it is anticipated that government expenditure on education will have a positive relationship with GDP.

\section{Methodology}

The econometric methodology adopted in this paper has three main stages. In the first step of the analysis, we determine the order of integration of the variables included in our models. To achieve this objective we use two unit root techniques. Namely, the augmented Dickey-Fuller (ADF), and the Generalized Least Squares, Dickey-Fuller test (DF-GLS) developed by Elliot, G., T. Rothenberg and J. Stock (1996). This is to make sure the robustness of our results given by the 
effect of financial development on economic growth. Most empirical studies, that depend on these theoretical approaches, suggested by several economic Schools of thought, may be divided into three categories. First, the structuralists claimed that the quantity and composition of financial variables stimulates economic growth by directly increasing savings in the form of financial assets, as a result encouraging capital accumulation and therefore, economic growth. Second, the repressionists, the financial repressionists, often referred to as followers of the "Mckinnon-Shaw" hypothesis, proposed by McKinnon (1973), Shaw (1973) and Fry (1978) stated that financial liberalization in the form of a suitable rate of return on real cash balances is a vehicle of encouraging economic growth. The crucial idea of this hypothesis is that a more liberalized financial system will stimulate an increase in savings and investment and as a result promote economic growth. Third, the endogenous growth theory supporters, that have come up to similar conclusions with the McKinnonShaw hypothesis by explicitly modeling the services provided by financial intermediaries such as risk-sharing and liquidity provision, (see Vazakids and Adamopoulos, 2009; pp. 1410-1411).

The relationship between financial development and economic growth has been investigated empirically in the literature such as Gupta (1984), Jung (1986), King and Levine (1993 a, b), Murinde and Eng (1994), De Gregorio and Guidotti (1995), Demetriades and Hussein (1996), Mohsin and Khan and Senhadji (2000) and Wachtel, (2001) among others. The huge and growing literature on this issue can be summarized under two major trends. On the one hand, cross country and panel data studies discover a positive effect of financial development on output growth. On the other hand, the majority of time series studies discover either unidirectional causality from finance to growth or bi-directional causality, see Kar. M. , Nazlioglu and Agir, H. (2010).

Recent empirical studies find positive and significant relationship between financial development and economic growth; see Seetanah (2008) and Odhiambo (2010) among others. Seetanah (2008) examines the dynamic empirical relationship between financial development and economic growth performance for the case of developing island state of Mauritius over the span 1952-2004, employing two different measures for financial development in an ARDL approach. The results indicate that financial development has been contributing to the economic growth in 


\section{Objective and the Importance of the Study}

The aim of this study is to investigate the long-run relationship between economic growth, financial development, human capital and trade openness. This study contributes to the existing literature on the relationship between financial development and economic growth in two ways. To the best of my knowledge, this study is the first to apply the multivariate co-integration and causality approach to Saudi Arabia as a specific country, to explain the interrelationship between financial development, human capital and economic growth. We also use the relatively new, and yet little used, bounds testing approach to cointegration, within an autoregressive distributed lag (ARDL) model, see Pesaran et al. (2001).

We choose Saudi Arabia, because it is above all an attractive case study of the finance-growth nexus. Since the late 1930s, when Saudi Arabia discovered oil, it has had one of the highest grown rates of any country amongst the developing countries, especially in the Middle East. At the same time, it has experienced a large increase in money supply, bank deposits and credit provided to the private sector by commercial banks. For example, the broad money supply (M3) increased from SR 1628 million in 1963 to SR 929,125 million in 2008. Similarly, credit to the private sector and bank deposits increased from SR 809 million and SR783 million to SR 734,557 million and SR 846,119 million, respectively, in the same period. Note also that human capital accumulation in Saudi Arabia has increased rapidly since 1932. The estimated numbers of all students in schools were 143,000 in 1960, while the number of students in general education in 2006 was more than 4.6 million, see SAMA, $45^{\text {th }}$ Annual Report (2009, pp. 263-395).

\section{Literature Review}

\subsection{Financial Development and Economic Growth}

The relationship between financial development and the real economy has received a great attention in recent theoretical and empirical studies. The theoretical underpinnings of this relationship can be found in the works of Bagehot (1873) and Schumpeter (1911) and more recently in the works of Gurley and Shaw (1955) and (1960), McKinnon (1973), Shaw (1973) and Lucas (1988). Theory provides conflicting sides for the 


\section{Introduction}

There is a large literature that investigates the finance-growth nexus, and the exports-growth nexus, within a bi-variate framework (see Ahmed (2001) and Ang (2008) for recent survey). There is also a considerable literature that investigates the relationship between economic growth and human capital investment. However, with the exception of a study by Trabelsi (2002), little attention has been drawn to Arab countries regarding the causal relationship between financial development, human capital, trade openness and economic growth within a multivariate approach.

Recent decades, several developing countries have adopted development plans that give priority to the modernization of their financial sector. Saudi Arabia is no exception. Since the mid-1990s Saudi Arabia has been interested in accelerating financial development; for instance, by reducing government intervention in the economy and by privatizing public corporations such as telecommunications and the postal services. Such policies have been anticipated to promote growth through a higher mobilization of savings or a rise in domestic and foreign investment.

Studies using time series techniques for developing countries have been scarce and to my knowledge only a few studies have been done for the case of Arab countries. The purpose of this paper is to examine the empirical link between financial development and economic growth in the presence of a human capital indicator as well as trade openness in Saudi Arabia, using time series data over the period 1970-2008.

The structure of the paper is as follows: Section two presents the objective and the importance of the study. Section three reviews the literature associated with the main areas of interest in this study. Section four describes the preferred methodology and presents the models and discusses variables and data sources. Section five provides empirical results. Finally, Section five concludes. 


\title{
Financial Development, Human Capital and Output Growth in Saudi Arabia
}

\author{
Abdullah M. Al-Malki \\ Assistant Professor of Economics \\ Department of Administrative Science \\ King Saud University, Riyadh, KSA \\ amalmalki@ksu.edu.sa
}

(Received 12-6-1433H, accepted 27-11-1433H)

\begin{abstract}
This paper investigates the relationship between financial development, human capital and economic growth in Saudi Arabia over the period 1970-2008. The empirical analysis is based on the newly developed method of co-integration along with the popular time series methodologies such as the Engle and Granger (1987), Johansen and Juselius (1990) and Granger causality. The co-integration tests reveal the presence of long run equilibrium relationship between financial development, human capital and economic growth. The Granger causality tests indicate the existence of bidirectional causality between human capital and economic growth, and between openness and economic growth. It also confirms the unidirectional causality from financial development to economic growth. The policy implication of this study is that the Saudi government should develop the financial sector even more and carry out the necessary procedures to strengthen the relationship between the financial sector and the real economy.
\end{abstract}

Keywords: Financial development, Economic growth, ARDL co-integration, Causality, Saudi Arabia.

JEL Classification: C32 O16 O43. 